Archives de sciences sociales des religions

136 | octobre - décembre 2006

Les Archives... cinquante ans après

\title{
Bruno Béthouart, Alain Lottin, éds., La dévotion mariale de l'an mil à nos jours
}

Arras, Artois Presses Université, 2005, 453 p.

Liliane Voyé

\section{(2) OpenEdition}

\section{Journals}

Édition électronique

URL : http://journals.openedition.org/assr/3869

DOI : 10.4000/assr.3869

ISSN : $1777-5825$

\section{Éditeur}

Éditions de l'EHESS

Édition imprimée

Date de publication : 1 décembre 2006

Pagination : 115-283

ISBN : 2-7132-2124-2

ISSN : 0335-5985

\section{Référence électronique}

Liliane Voyé, « Bruno Béthouart, Alain Lottin, éds., La dévotion mariale de l'an mil à nos jours », Archives de sciences sociales des religions [En ligne], 136 | octobre - décembre 2006, document 136-15, mis en ligne le 12 février 2007, consulté le 21 septembre 2020. URL : http://journals.openedition.org/assr/ 3869 ; DOI : https://doi.org/10.4000/assr.3869

Ce document a été généré automatiquement le 21 septembre 2020

(C) Archives de sciences sociales des religions 


\title{
Bruno Béthouart, Alain Lottin, éds., La dévotion mariale de l'an mil à nos
} jours

Arras, Artois Presses Université, 2005, 453 p.

\author{
Liliane Voyé
}

1 Cet ouvrage propose les actes d'un colloque international, tenu à Boulogne-sur-Mer en mai 2003, et qui s'était donné pour objectif d'explorer mille ans de culte marial en Europe du Nord-Ouest, sans toutefois que cette délimitation géographique n'ait conduit à exclure l'évocation d'autres espaces. À travers des études de cas, notamment de Vierges particulières (celles de Boulogne, Fatima, Montaigu, Czestochowa, Guadalupe...) ou de contextes spécifiques (guerres, conflits religieux, confréries...), les diverses contributions rassemblées soulignent tout à la fois les constantes qui étayent le culte marial et les variations qui le traversent. Sans doute, pour une large majorité du " peuple » (ce terme étant à entendre sans aucune connotation sociale), Marie apparaîtelle avant tout comme figure de recours et de secours, et ce de façon assez continue à travers le temps et l'espace. Mais, selon les moments et les lieux, elle est aussi sollicitée par divers acteurs porteurs de l'un ou l'autre pouvoir pour servir de garant, de référence ou de modèle à différents rôles sociaux, de la reine à la servante ou de la mère à la guerrière, elle est instrumentalisée pour venir soutenir les causes religieuses ou politiques les plus diverses: soutien de princes, stratégie missionnaire, nationalisme, lutte contre la république, le communisme ou le socialisme. La figure de Marie s'avère ainsi largement malléable et polymorphe et se prête donc aisément à des réappropriations multiples et éventuellement contradictoires.

2 À côté de ce fil conducteur majeur, l'ouvrage propose également quelques contributions qui évoquent les formes d'art associées au culte marial, les types de dévotions qui l'accompagnent ou, encore, les positions officielles de l'Église-institution face à ce phénomène largement répandu.

3 Si ce livre offre de multiples informations et ressources descriptives intéressantes, on peut regretter que, tout au moins dans une synthèse critique, il ne propose pas une 
analyse plus théorique, recadrant les nombreuses contributions qui le composent dans une perspective plus interprétative et explicative. L'ensemble reste fragmentaire alors que la richesse du matériau se prêterait à une relecture transversale qui fait défaut. 